\title{
Pergeseran Kekuatan Akta Autentik Serta Kewenangan Notaris Dalam Pembuatan Akta Pendirian Koperasi (Pasca Putusan Mahkamah Konstitusi No. 28/PUU-XI/2013)
}

\author{
Muhammad Gondo Ratangin \\ Magister Kenotariatan Universitas Islam Indonesia \\ Perumahan Taman Siswa Indah Blok E-2, Wirogunan, Yogyakarta \\ gondolondo@gmail.com
}

\begin{abstract}
This study describes the legal force Establishment of Cooperative deed of Notary after the Constitutional Court ruling No. 28 / PUU-XI / 2013, as well as analyzing the legal implications of the Minister of Cooperatives and SMEs towards authority in making Cooperation Deed Notary. This research is a field research by using juridical empirical approach. The study concluded, first: the power of cooperative law deed of Notary after the Constitutional Court ruling No. 28 / PUU-X / 2013 resulted in a shift in the regulations regarding cooperatives for the time that is returned to Act No. 25 of 1992 concerning Cooperatives until enactment of the new law. Therefore, the whole procedure and the establishment of cooperatives from the date of repeal of Act No. 17 of 2012 concerning Cooperatives by the Constitutional Court back in Act No. 25 of 1992 concerning Cooperatives and all implementation regulations. Secondly, the implications of Ministerial Decree No. 98 / KEP / M.KUKM / IX / 2004 regarding Notary Public as Cooperation Deed, making Notary public official authority in this case to serve the public in the process of making authentic evidence in accordance with the authority granted by UUJN- $P$, is limited, because the authority of the notary is a deed authentic under the Act, unless another Specifies Act.
\end{abstract}

Keywords: Notary, NPAK, cooperatives, shift deeds, deed of cooperation

\begin{abstract}
Abstrak
Penelitian ini memaparkan kekuatan hukum akta Pendirian Koperasi yang dibuat oleh Notaris pasca Putusan MK No. 28/PUU-XI/2013, serta menganalisa implikasi hukum Keputusan Menteri Koperasi dan UKM terhadap kewenangan Notaris dalam pembuatan Akta Koperasi. Penelitian ini bersifat penelitian lapangan dengan menggunakan pendekatan yuridis empiris. Hasil penelitian menyimpulkan, pertama: kekuatan hukum akta koperasi yang dibuat oleh Notaris pasca Putusan MK No. 28/PUU-XI/2013 mengakibatkan terjadinya pergeseran peraturan tentang perkoperasian untuk sementara waktu yakni kembali pada Undang-undang Nomor 25 Tahun 1992 tentang Perkoperasian sampai diterbitkannya Undang-undang baru. Oleh karena itu seluruh prosedur dan tata cara pendirian koperasi sejak tanggal dicabutnya Undang-undang Nomor 17 Tahun 2012 tentang Perkoperasian oleh Mahkamah Konstitusi kembali pada Undang-undang Nomor 25 Tahun 1992 tentang Perkoperasian beserta seluruh peraturan pelaksanaanya. Kedua, implikasi Keputusan Menteri Nomor 98/KEP/M.KUKM/IX/2004 tentang Notaris Sebagai Pembuat Akta Koperasi, menjadikan wewenang Notaris sebagai pejabat publik dalam hal ini melayani masyarakat umum dalam proses pembuatan alat bukti autentik sesuai dengan kewenangan yang diberikan oleh UUJN-P, menjadi terbatas, karena kewenangan Notaris adalah membuat akta autentik berdasarkan Undang-undang, kecuali Undang-undang Menentukan lain.
\end{abstract}

Kata Kunci: Notaris, NPAK, perkoperasian, pergeseran akta, akta koperasi 


\section{Pendahuluan}

Putusan Mahkamah Konstitusi No. 28/PUU-XI/2013, terhadap Pasal 1 angka 1 Undang-undang Nomor 17 Tahun 2012 tentang Perkoperasian yang menyebut koperasi sebagai badan hukum tidak mengandung pengertian substantif, merujuk pada pengertian sebagai bangunan perusahaan khas. Hal ini tidak sejalan dengan koperasi seperti dimaksud Pasal 33 ayat (1) UUD Tahun 1945, dan menurut Undang-undang Nomor 25 Tahun 1992 tentang Perkoperasian yang berlaku kembali pasca Mahkamah Konstitusi membatalkan Undang-Undang Nomor 17 Tahun 2012 tentang Perkoperasian yang menyatakan bahwa:

"Koperasi adalah badan usaha yang beranggotakan orang-orang atau badan hukum koperasi dengan melandaskan kegiatannya berdasarkan prinsip koperasi sekaligus sebagai gerakan ekonomi rakyat yang berdasarkan atas asas kekeluargaan. Koperasi adalah suatu perkumpulan yang beranggotakan orang seorang atau badan-badan hukum, yang memberikan kebebasan bagi anggotanya untuk masuk atau keluar dari koperasi dan bekerja sama secara kekeluargaan dalam menjalankan usahanya untuk mempertinggi kesejahteraan para anggotanya."

Apabila dilihat dari semangat reformasi dan demokrasi, kembali berlakunya Undang-Undang Nomor 25 Tahun 1992 tentang Perkoperasian adalah bentuk reformasi sektor koperasi yang ditempatkan pada masa transisi, dimana disatu pihak sudah muncul dan berkembang pandangan-pandangan baru yang dianggap tidak sejalan dengan prinsipprinsip perkoperasian di Indonesia dan dibatalkan (Undang-Undang Nomor 17 Tahun 2012), tetapi dilain pihak antara lain di bidang hukum yang tersedia adalah sarana hukum yang lama yang dianggap juga tidak memiliki sifat untuk memberikan akomodasi terhadap tuntutan atas dasar/prinsip-prinsip koperasi.

Undang-Undang Nomor 25 Tahun 1992 meski diberlakukan kembali sebetulnya belum menyelesaikan permasalahan yang ada pada koperasi khususnya terkait dengan pembentukan badan hukum yang dilakuan oleh pejabat umum, di dalam Undang-undang tersebut tidak menjelaskan atau mengatur tentang pejabat mana yang berwenang untuk mengesahkan anggaran dasar serta perubahannya bagi koperasi, berbeda dengan UndangUndang Nomor 17 Tahun 2012 Pasal 9 ayat (1) yang secara eksplisit menyebutkan bahwa akta pendirian koperasi dibuat oleh Notaris dalam bahasa Indonesia.

Koperasi sebagai badan usaha belum dapat berkembang dan bersaing dengan pelaku bisnis lainnya, salah satu faktornya yang cukup mendasar adalah lemahnya kedudukan Koperasi sebagai badan usaha yang harus menjadi perusahaan yang tangguh dan efisien berdasarkan prinsip koperasi dan kaedah umum yang berlaku dalam dunia bisnis modern. 
Salah satu penyebabnya karena proses pembentukan, perubahan dan pembubaran koperasi selama ini dilakukan berdasarkan dokumen-dokumen yang berupa akta di bawah tangan, sebelum disahkan oleh pejabat yang berwenang. ${ }^{1}$

Koperasi sebagai salah satu pelaku bisnis memerlukan pula adanya kepastian hukum menyangkut dokumen-dokumen yang dibuatnya. Akta-akta yang dibuat oleh di lingkungan koperasi masih merupakan akta di bawah tangan, hal ini disebabkan Undang-undang Nomor 25 Tahun 1992 tentang Perkoperasian tidak mengharuskan bahwa akta-akta Koperasi harus dalam bentuk akta autentik, berbeda dengan Undang-Undang Nomor 17 Tahun 2012 tentang Perkoperasian yang mengatur peran Notaris dalam pembuatan akta pendirian koperasi sesuai Pasal 9 ayat (1) Pendirian Koperasi sebagaimana dimaksud dalam Pasal 7 dilakukan dengan Akta Pendirian Koperasi yang dibuat oleh Notaris dalam bahasa Indonesia yang telah dibatalkan oleh Mahkamah Konstitusi, begitu juga belum ada kesadaran dari pelaku koperasi itu sendiri untuk membuatkan akta-aktanya dalam bentuk autentik. Akibatnya maka akta-akta Koperasi tersebut kurang memberikan keyakinan sebagai alat bukti yang kuat.

Pejabat yang selama ini memberikan bantuan dalam penyusunan akta pendirian Koperasi meskipun sudah diberikan pelatihan-pelatihan khusus untuk itu masih dianggap kurang memenuhi kualifikasi yang dibutuhkan untuk menjadikan akta yang dibuatnya sebagai akta autentik. Di samping itu pejabat tersebut tidak diberi bekal yang cukup tentang dasar-dasar teknik pembuatan akta serta materi-materi hukum lainnya sebagai pendukung jabatannya dalam memberikan nasehat-nasehat berkaitan dengan keberadaan Koperasi sebagai badan hukum dan badan usaha dalam melakukan kegiatan bisnis. ${ }^{2}$

Akta autentik adalah akta yang dibuat oleh pejabat yang diberi wewenang untuk itu oleh penguasa, menurut ketentuan-ketentuan yang telah ditetapkan, baik dengan maupun tanpa bantuan dari yang berkepentingan, yang mencatat apa yang dimintakan untuk dimuat di dalamnya oleh yang berkepentingan. ${ }^{3}$ Akta autentik juga memuat keterangan seorang pejabat tentang apa yang dilakukannya dan dilihat dihadapannya. ${ }^{4}$

Pasal 1868 KUHPerdata menyebutkan bahwa Suatu akta autentik ialah suatu akta yang dibuat dalam bentuk yang ditentukan Undang-undang oleh atau dihadapan pejabat umum yang berwenang untuk itu ditempat akta itu dibuat.

Ketentuan yang terdapat pada Pasal 1868 KUHPerdata, untuk dapat membuat akta autentik seseorang harus mempunyai kedudukan sebagai "pejabat umum“. Pejabat umum

\footnotetext{
${ }^{1}$ LPS21, Kajian Akademik Rancangan Undang-undang Koperasi, Jakarta, 2001, hlm. 64.

2 Suroto, Pelatihan Perkoperasian, Jakarta, 2015, hlm. 4.

3 Sudikno Mertokusumo, Hukum Acara Perdata Indonesia, edisi keempat, Liberty, Yogyakarta, 1993, hlm. 123.

${ }^{4}$ Ibid, hlm. 123.
} 
diberi wewenang dan kewajiban untuk melayani publik dalam hal-hal tertentu yang tidak dapat dilakukan sendiri oleh pemerintah secara langsung.

Seseorang yang diangkat menjadi pejabat umum tersebut ikut serta dalam melaksanakan kewibawaan dari pemerintah, karena dalam jabatannya pejabat umum memiliki sifat atau ciri yang khas untuk membedakan dengan jabatan-jabatan lainnya dalam masyarakat, meskipun untuk menjalankan jabatan tersebut diperlukan pengangkatan atau ijin dari pemerintah.

Berdasarkan Pasal 1 angka 1 Undang-Undang No 2 Tahun 2014 tentang Perubahan Atas Undang-Undang Nomor 30 Tahun 2004 tentang Jabatan Notaris (selanjutnya disebut UUJN-P), Notaris adalah pejabat umum yang berwenang untuk membuat akta autentik dan memiliki kewenangan lainnya sebagaimana dimaksud dalam Undang-undang Jabatan Notaris atau berdasarkan Undang-undang lainnya.

Atas dasar kenyataan yang terjadi dalam pembuatan Akta Pendirian di bidang perkoperasian, maka Menteri Koperasi dan Usaha Kecil dan Menengah Republik Indonesia memberlakukan kembali Keputusan Nomor 98/KEP/M.KUKM/IX/2004 tentang Notaris sebagai Pejabat Pembuat Akta Koperasi pasca pembatalan Undang-Undang Nomer 17 Tahun 2012 tentang Perkoperasian oleh MK melalui surat edaran Kementerian Koperasi dan UKM No. 169/SE/Dep.1NI/2014, dalam hal ini apakah Keputusan Menteri Koperasi tersebut mempunyai kekuatan hukum berkaitan dengan akta autentik yang dibuat oleh Notaris sebagai Pejabat Umum melalui keputusan menteri tersebut bila di sandingkan dengan Undang-undang Jabatan Notaris serta arti sesungguhnya akta autentik itu sendiri mengacu pada ketentuan Pasal 1868 KUHPerdata.

Pasal 3 ayat (1) Keputusan Menteri Negara Koperasi dan Usaha Kecil dan Menengah Nomor 98/KEP/M.KUKM/IX/2004 menyebutkan, Notaris diberi tugas pokok untuk membuat akta autentik sebagai bukti telah dilakukannya suatu perbuatan hukum tertentu dalam proses pendirian, perubahan anggaran dasar serta akta-akta lainnya yang terkait dengan kegiatan Koperasi yang kemudian untuk dimohonkan pengesahannya kepada pejabat yang berwenang.

Pasal 3 ayat (2) Keputusan Menteri Negara Koperasi dan Usaha Kecil dan Menengah Nomor 98/KEP/M.KUKM/IX/2004, Notaris mempunyai tugas pokok meliputi pembuatan: akta pendirian Koperasi, akta perubahan anggaran dasar Koperasi dan akta-akta lain yang terkait dengan kegiatan Koperasi. Apakah peraturan Menteri Koperasi terkait keautentikan Akta Koperasi serta merta dapat memberikan perlindungan dan kepastian hukum bagi masyarakat yang membentuk Koperasi. 
Dalam pasal-pasal Undang-undang Nomor 25 Tahun 1992 tentang Perkoperasian tidak mensyaratkan anggaran dasar Koperasi untuk dibuat secara autentik, namun disyaratkan untuk dibuat secara tertulis bisa dengan akta di bawah tangan atau dengan akta autentik. Sehingga memberi kebebasan kepada orang-orang yang akan mendirikan Koperasi untuk memilih dengan akta di bawah tangan atau meminta bantuan Notaris dengan akta autentik, disini saya kira akan menjadi ketidak pastian hukum terhadap keabsahan antara akta yang dibuat dibawah tangan dengan akta yang di buat dihadapan Notaris. Untuk menunjukkan bahwa kewenangan Notaris sebagai pejabat umum telah sempurna, artinya tidak diperlukan syarat lain, Notaris sebagai pembuat akta koperasi berdasarkan Keputusan Menteri Negara Koperasi dan Usaha Kecil dan Menengah Republik Indonesia Nomor 98/KEP/M.KUKM/IX/2004, tentang Notaris sebagai pembuat akta koperasi, Pemberian sebutan lain kepada Notaris seperti tersebut di atas, akan menciderai makna pejabat umum. Seakan-akan Notaris akan mempunyai kewenangan tertentu jika disebutkan dalam suatu aturan hukum dari instansi pemerintah dalam hal ini hanya berupa Keputusan Menteri.

\section{Rumusan Masalah}

Penelitian ini mengkaji dua permasalahan, pertama, bagaimana kekuatan hukum akta Pendirian Koperasi yang dibuat oleh Notaris pasca Putusan Mahkamah Konstitusi Nomor 28/PUU-XI/2013? Kedua, bagaimanakah implikasi hukum Keputusan Menteri Negara Koperasi dan Usaha Kecil dan Menengah Republik Indonesia Nomor 98/KEP/M.KUKM/IX/2004, tentang Notaris sebagai pembuat akta koperasi?

\section{Tujuan Penelitian}

Penelitian ini bertujuan untuk mengetahui dan menganalisis: pertama, kekuatan hukum akta pendirian Koperasi yang dibuat oleh Notaris pasca Putusan Mahkamah Konstitusi Nomor 28/PUU-XI/2013 yang menjadikan Koperasi Badan hukum. Kedua, implikasi hukum Keputusan Menteri Negara Koperasi dan Usaha Kecil dan Menengah Republik Indonesia Nomor 98/KEP/M.KUKM/IX/2004, tentang Notaris sebagai pembuat akta koperasi.

\section{Metode Penelitian}

Metode penelitian ini adalah yuridis empiris, Spesifikasi penelitian ini adalah deskriptif analitis. Deskriptif karena penelitian ini bertujuan memperoleh gambaran secara rinci, sistematis, dan menyeluruh mengenai pergeseran kekuatan hukum akta autentik serta kewenangan Notaris dalam pembuatan akta pendirian koperasi (pasca putusan 
MK No. 28/PUU-XI/2013). Bersifat analitis yaitu dengan cara menganalisa data yang diperoleh dari perundang-undangan yang berlaku, pendapat para ahli, dan teori-teori ilmu hukum yang berkaitan dengan kewenangan Notaris sebagai pejabat umum didalam pembuatan akta pendirian koperasi.

\section{Hasil Penelitian dan Pembahasan}

\section{Kekuatan Hukum Akta Koperasi yang Dibuat Oleh Notaris Pasca Putusan Mahkamah Konstitusi Nomor 28/PUU-XI/2013}

Perbandingan antara Undang-Undang Nomor 25 Tahun 1992 dengan UndangUndang Nomor 17 Tahun 2012 mengenai akta pendirian koperasi, dalam Undang-Undang Nomor 25 Tahun 1992 tidak disebutkan secara tegas bahwa Notaris yang membuat akta pendirian koperasi adalah Notaris yang merupakan pejabat pembuat akta koperasi yang terdaftar pada kementerian yang menyelenggarakan urusan pemerintahan di bidang koperasi. Hal ini berbeda dengan ketentuan dalam Undang-Undang Nomor 17 Tahun 2012 yang mewajibkan bahwa Notaris pembuat akta pendirian koperasi adalah Notaris yang merupakan pejabat pembuat akta koperasi yang telah terdaftar pada kementerian yang menyelenggarakan urusan pemerintahan di bidang koperasi. ${ }^{5}$

Putusan Mahkamah Konstitusi No. 28/PUU-IX/2013 juga mengakibatkan terjadinya pergeseran pengaturan Undang-undang tentang perkoperasian untuk sementara waktu yakni kembali pada Undang-Undang Nomor 25 Tahun 1992 tentang Perkoperasian sampai diterbitkannya Undang-undang baru tentang perkoperasian tersebut. Oleh karena itu seluruh prosedur dan tata cara pendirian koperasi sejak tanggal dicabutnya Undang-undang Nomor 17 Tahun 2012 tentang Perkoperasian oleh Mahkamah Konstitusi kembali pada UndangNomor 25 Tahun 1992 tentang Perkoperasian beserta seluruh peraturan pelaksanaanya. ${ }^{6}$ Akibat hukum yang timbul terhadap Notaris dalam membuat akta pendirian koperasi pasca keluarnya Putusan Mahkamah Konstitusi Nomor 28/PUU-XI/2013 adalah bahwa Undangundang Nomor 17 Tahun 2012 tentang Perkoperasian bahwa Notaris tidak lagi dapat membuat akta pendirian koperasi berdasarkan prosedur dan tata cara sebagaimana diatur dalam Undang-Undang Nomor 17 Tahun 2012 tentang Perkoperasian, karena Undangundang tersebut tidak lagi memiliki kekuatan hukum yang mengikat sebagai Undang-

${ }^{5}$ Hadi Kusuma, Koperasi Indonesia, Raja Grafindo Persada, Jakarta, 2006, hlm. 62.

${ }^{6}$ Orriza Julia Ervianty, "Analisis Hukum Atas Tugas dan Peranan Notaris Dalam Pendirian Koperasi Sebelum dan Setelah Berlakunya Undang-undang Nomor 17 Tahun 2012 Tentang Perkoperasian dan Pasca Keluarnya Putusan Mahkamah Konstitusi Republik Indonesia Nomor 28/PUU-XI/2013", Jurnal Hukum, hlm. 11. 
undang, sehingga dinyatakan tidak berlaku lagi dalam pengaturan koperasi dan mengakibatkan Notaris wajib mengikuti pengaturan hukum koperasi yang termuat di dalam Undang-Undang Nomor 25 Tahun 1992 tentang Perkoperasian serta pelaksanaanya. Disamping itu koperasi yang didirikan berdasarkan Undang-Undang Nomor 17 Tahun 2012 tentang Perkoperasian tetap sah secara hukum namun harus menyesuaikan dengan Anggaran Dasar dan Anggaran Rumah Tangganya sesuai dengan ketentuan UndangUndang Nomor 25 Tahun 1992 tentang Perkoperasiaan beserta seluruh peraturan pelaksanannya. Notaris dalam pembuatan akta pendirian koperasi yang baru wajib menggunakan prosedur dan tata cara sesuai ketentuan Undang-Undang Nomor 25 Tahun 1992 tentang Perkoperasian serta peraturan pelaksananya. ${ }^{7}$

Pendirian koperasi pasca putusan Mahkamah Konstitusi Nomor 28/PUU-XI/2013, Pengesahan Badan Hukum Koperasi dan Perubahan Anggaran Dasar sejak tanggal 28 Mei 2014 dilakukan berdasarkan Undang-undang Nomor 25 Tahun 1992 Tentang Perkoperasian dan Peraturan Pelaksanaannya.

Dalam proses penerbitan akta Koperasi, Notaris sebagai Pembuat Akta Koperasi dapat menyesuaikan kembali proses tersebut berdasarkan:

a. Undang-undang Nomor 25 Tahun 1992 tentang Perkoperasian.

b. Peraturan Menteri Negara Koperasi dan UKM Nomor 01/Per/M.KUKM///2006 tentang Petunjuk Pelaksanaan Pembentukan, Pengesahan Akta Pendirian dan Anggaran Dasar Koperasi

c. Keputusan Menteri Negara Koperasi dan UKM Nomor 98/Kep/M.KUKM/IX/2004 tentang Notaris sebagai Pembuat Akta Koperasi.

Notaris sebagai pejabat umum yang berwenang membuat akta autentik, hal ini berdasarkan pada Pasal 1 angka 1 Undang-Undang Nomor 2 Tahun 2014 tentang Perubahan atas Undang-Undang Nomor 30 Tahun 2004 tentang Jabatan Notaris, yang menyebutkan "Notaris adalah pejabat umum yang berwenang untuk membuat akta autentik dan memiliki kewenangan lainnya sebagaimana dimaksud dalam Undang-undang lainnya." "Sedangkan mengenai akta Notaris atau berdasarkan Pasal 1 angka 7 UUJN-P adalah "akta autentik yang dibuat oleh atau di hadapan Notaris menurut bentuk dan tata cara yang telah ditetapkan dalam Undang-undang ini." ${ }^{, 9}$ Hal ini termasuk kewenangan Notaris dalam membuat akta pendirian koperasi. Undang-undang Nomor 25 Tahun 1992 tentang Perkoperasian bukan suatu keharusan dalam pendirian akta koperasi dengan akta notariil, namun pada prakteknya

${ }^{7}$ Ibid.

${ }^{8}$ Lihat Pasal 1 angka 1 UUJN-P

${ }^{9}$ Lihat Pasal 1 angka 7 UUJN-P 
para pendiri koperasi pada umumnya menggunakan akta Notaris dalam pelaksanaan pendirian koperasi.

Kedudukan Notaris sebagai pejabat umum, dalam arti kewenangan yang ada pada Notaris tidak pernah diberikan kepada pejabat-pejabat lainnya, sepanjang kewenangan tersebut tidak menjadi kewenangan pejabat-pejabat lain dalam membuat akta autentik dan kewenangan lainnya, maka kewenangan tersebut menjadi kewenangan Notaris.

Kewenangan Notaris di samping diatur dalam Pasal 15 undang-undang Jabatan Notaris, juga ada kewenangan yang ditegaskan dalam peraturan perundang-undangan yang lain, dalam arti peraturan perundang-undangan yang bersangkutan menyebutkan / menegaskan agar perbuatan hukum tertentu wajib dibuat dengan akta Notaris.

Menindaklanjuti aturan mengenai pendirian koperasi, Kementerian Koperasi dan Usaha Kecil dan Menengah dengan Ikatan Notaris Indonesia (INI) pada 4 Mei 2004, menandatangani MoU atau nota kesepakatan, maka hal ini menjadikan wewenang Notaris semakin luas, hal ini dikarenakan dalam Undang-Undang Nomor 25 Tahun 1992 tentang Perkoperasian tidak menyebutkan satu pasal pun yang mengharuskan bahwa Anggaran Dasar suatu Koperasi hanya disyaratkan dalam bentuk akta (autentik) yaitu dengan kata lain bisa dibuat dengan akta di bawah tangan atau akta autentik, hal ini disimpulkan dalam Pasal 7 ayat (1) Undang-Undang Nomor 25 Tahun 1992 tentang Perkoperasian yang menyatakan "pembentukan koperasi sebagaimana dimaksud dalam Pasal 6 dilakukan dengan akta pendirian yang memuat anggaran dasar".

Ketentuan tentang pendirian dan perubahan Anggaran Dasar koperasi yang diatur dalam Undang-undang Koperasi memberikan kebebasan kepada orang-orang yang mendirikan koperasi untuk memilih dengan akta di bawah tangan dengan tanpa melibatkan pejabat umum dengan akta autentik. ${ }^{10}$

Isi dari MoU antara Kementerian Koperasi dan Usaha Kecil dan Menengah dengan Ikatan Notaris Indonesia antara lain bahwa Kementerian Koperasi dan Usaha Kecil dan Menengah dengan Ikatan Notaris Indonesia sepakat untuk bekerja sama menyelenggarakan suatu pembekalan bagi seluruh anggota INI dan memberikan sertifikasi kepada para Notaris, dan diberi wewenang membuat akta koperasi yang meliputi akta pendirian, perubahan berita acara, dan akta-akta lain yang berkaitan dengan itu. ${ }^{11}$

\footnotetext{
${ }^{10}$ H. Budi Untung, Hukum Koperasi dan Peranan Notaris Indonesia, ANDI, Yogyakarta, 2007, hlm. 29.

11 Nota Kesepahaman (MoU) Kementerian Koperasi dan UKM RI dengan Ikatan Notaris Indonesia (INI) tertanggal 4 Mei 2004.
} 
Maka dari itu jelas bahwa, akta yang dibuat oleh/di hadapan Notaris pasca Keputusan Mahkamah Konstitusi Nomor 28/PUU-XI/2013, tetap merupakan akta autentik, hanya saja mengalami pergeseran dengan kembalinya kepada Undang-undang Nomor 25 Tahun 1992 tentang Perkoperasian, dan menyesuaikan AD dan ART serta aturan pelaksanaannya, serta akta tersebut tetap memiliki nilai/kekuatan pembuktian: a. Kekuatan pembuktian lahiriah (Uitwendige Bewijsracht); b. Kekuatan pembuktian Formal (Formale Bewijskracht); c. Kekuatan Materil (meteriele bewijskracht).

Secara politis konstitusional, kedudukan koperasi di Indonesia begitu kuat dan strategis. Yakni tercantum dalam UUD 1945. Dan mengingat UUD 1945 merupakan Undang-undang tertinggi dan merupakan hukum dasar bagi berlakunya semua peraturan perundang-undangan di wilayah hukum Republik Indonesia, maka kesadaran hukum dalam arti antara lain: tunduk, patuh, disertai penghayatan dan pengamalan UUD 1945, wajib dilaksanakan oleh setiap warga negara Indonesia. ${ }^{12}$

Pokok-pokok perbedaan antara Undang-undang Nomor 25 Tahun 1992 tentang Perkoperasin dengan Undang-Undang Nomor 17 Tahun 2012 tentang Perkoperasin, khususnya dalam hal ini adalah perbedaan dalam hal pendirian koperasi yaitu Akta Koperasi. Dalam Undang-Undang Nomor 25 Tahun 1992 tentang Perkoperasian menyatakan:

1) Akta pendirian koperasi tidak harus menggunakan akta otentik.

2) Jangka waktu pengesahan paling lama 3 bulan sejak tanggal permintaan.

3) Tidak diatur mengenai penamaan koperasi.

4) Tidak diatur mengenai jangka waktu berdirinya koperasi.

5) Tidak diatur mengenai larangan dilakukannya perubahan anggaran dasar saat operasi dinyatakan pailit. (BAB IV, Pasal 6 s/d 16)

Sedangkan dalam Undang-Undang Nomor 17 Tahun 2012 tentang Perkoperasin, antara lain:

1) Pendirian koperasi dilakukan dengan akta Notaris/camat dan status badan hukumnya disahkan oleh Menteri.

2) Pengesahan tersebut diberikan dalam jangka waktu paling lama 30 hari sejak tanggal permohonan.

3) Mengatur tentang pemakaian nama koperasi.

4) Jangka waktu berdirinya koperasi wajib diatur dalam Anggaran Dasar.

5) Perubahan anggaran dasar tidak dapat dilakukan pada saat koperasi dinyatakan pailit, kecuali dengan persetujuan pengadilan. (Pasal 9)

12 Sudarsono dan Edilidius, Koperasi Dalam Teori dan Praktik, Rineka Cipta, Jakarta, 2010, hlm. 76. 
Dengan adanya putusan Mahkamah Konstitusi Nomor 28/PUU-XI/2013 yang mencabut keberlakuan Undang-undang Nomor 17 Tahun 2012 tentang Perkoperasian tersebut sekaligus menyatakan berlakunya kembali Undang-undang Nomor 25 Tahun 1992 tentang Perkoperasian sampai dengan dikeluarkannya Undang-undang Koperasi yang baru. Keputusan Mahkamah Konstitusi Nomor 28/PUU-XI/2013 tersebut berakibat pula terhadap perubahan tugas dan peranan Notaris dalam pendirian koperasi yang sebelumnya mengacu kepada Undang-undang Nomor 17 Tahun 2012 menjadi kembali kepada Undang-undang Nomor 25 Tahun 1992 dengan segala konsekuensi hukumnya.

\section{Implikasi Keputusan Menteri Nomor 98/KEP/M.KUKM/IX/2004 tentang Notaris sebagai Pembuat Akta Koperasi}

Implikasi Keputusan Menteri Nomor 98/KEP/M.KUKM/IX/2004 tentang Notaris Sebagai Pembuat Akta Koperasi, menjadikan wewenang Notaris sebagai pejabat publik dalam hal ini melayani masyarakat umum dalam proses pembuatan alat bukti autentik sesuai dengan kewenangan yang diberikan oleh Undang-undang, khususnya di pasal 15 ayat (1) UUJN-P, menjadi terbatas, oleh karena itu peneliti membagi rumusan masalah ini terkait dengan justifikasi dan keabsahan dalam Implikasi Keputusan Menteri Nomor 98/KEP/M.KUKM/IX/2004 tentang Notaris Sebagai Pembuat Akta Koperasi:

\section{Justifikasi}

Pasal 1 angka 2 Peraturan Menteri Koperasi dan Usaha Kecil dan Menengah Republik Indonesia Nomor 10/Per/M.KUKM/IX/2015 Tentang Kelembagaan Koperasi, menyebutkan "Akta Pendirian Koperasi adalah perjanjian perikatan pembentukan badan hukum koperasi yang dibuat oleh para pendiri atau kuasanya dan ditandatangani dihadapan Notaris Pembuat Akta Koperasi dalam suatu rapat pembentukan koperasi yang memuat anggaran dasar."

Peraturan Menteri ini juga mengatur mengenai pengesahan akta pendirian koperasi yang terdapat dalam Pasal 6, yang menyebutkan: a. Para pendiri koperasi atau kuasanya mempersiapkan akta pendirian koperasi untuk diajukan kepada Notaris; b. Dalam penyusunan akta pendirian koperasi, para pendiri atau kuasanya dapat berkonsultasi dengan ahli perkoperasian yang didampingi oleh Notaris; c. Para pendiri koperasi atau kuasanya mengajukan permohonan pengesahan akta pendirian koperasi secara tertulis kepada Pejabat yang berwenang melalui Notaris.

Jika Keputusan Menteri Negara Koperasi dan Usaha Kecil dan Menengah Nomor 98/Kep/M.KUKM/IX/2004 tentang Notaris Sebagai Pembuat Akta Koperasi dikaji secara 
mendalam berdasarkan Pasal 8 ayat (1) Undang-undang Nomor 12 Tahun 2011 tentang Tentang Pembentukan Peraturan Perundang-undangan, “jenis Peraturan Perundangundangan selain sebagaimana dimaksud dalam Pasal 7 ayat (1) mencakup peraturan yang ditetapkan oleh Majelis Permusyawaratan Rakyat, Dewan Perwakilan Rakyat, Dewan Perwakilan Daerah, Mahkamah Agung, Mahkamah Konstitusi, Badan Pemeriksa Keuangan, Komisi Yudisial, Bank Indonesia, Menteri, badan, lembaga, atau komisi yang setingkat yang dibentuk dengan Undang-undang atau Pemerintah atas perintah Undangundang, Dewan Perwakilan Rakyat Daerah Provinsi, Gubernur, Dewan Perwakilan Rakyat Daerah Kabupaten/Kota, Bupati/Walikota, Kepala Desa atau yang setingkat.”

Basuki, Assisten Deputi Bidang Perundang-undangan, Deputi Kelembagaan Kementerian Koperasi dan Usaha Kecil dan Menengah menyatakan ${ }^{13}$ bahwa secara formil terkait dengan Keputusan Menteri Negara Koperasi dan Usaha Kecil dan Menengah Nomor 98/Kep/M.KUKM/IX/2004 tentang Notaris Sebagai Pembuat Akta Koperasi terjadi kesalahan berdasarkan hierarki perundang-undangan di Indonesia. Apabila disandingkan dengan Undang-undang Nomor 2 Tahun 2014 tentang Jababatan Notaris, khususnya Pasal 15 ayat (1) mengenai kewenangan Notaris yang menyatakan bahwa "Notaris berwenang membuat akta autentik mengenai semua perbuatan, perjanjian, dan penetapan yang diharuskan oleh peraturan perundang-undangan dan/atau yang dikehendaki oleh yang berkepentingan untuk dinyatakan dalam akta autentik, menjamin kepastian tanggal pembuatan akta, menyimpan akta, memberikan grosse, salinan dan kutipan akta, semuanya itu sepanjang pembuatan akta itu tidak juga ditugaskan atau dikecualikan kepada pejabat lain atau orang lain yang ditetapkan oleh Undang-undang."

Kedudukan Keputusan Menteri Negara Koperasi dan Usaha Kecil dan Menengah Nomor 98/Kep/M.KUKM/IX/2004 tentang Notaris Sebagai Pembuat Akta Koperasi, Basuki memberikan pendapat bahwa karena belum terjadi permasalah di lapangan yang menyangkut tentang Keputusan Menteri Negara Koperasi dan Usaha Kecil dan Menengah Nomor 98/Kep/M.KUKM/IX/2004 tentang Notaris Sebagai Pembuat Akta Koperasi, maka Keputusan Menteri Negara Koperasi dan Usaha Kecil dan Menengah Nomor 98/Kep/M.KUKM/IX/2004 tentang Notaris Sebagai Pembuat Akta Koperasi ini tidak memiliki implikasi terhadap jalannya pendirian koperasi dan pengesahan sebagai badan hukum, Keputusan Menteri Negara Koperasi dan Usaha Kecil dan Menengah Nomor 98/Kep/M.KUKM/IX/2004 tentang Notaris Sebagai Pembuat Akta Koperasi ini hanya

${ }^{13}$ Hasil wawancara dengan Basuki, Assisten Deputi Bidang Perundang-undangan, deputi kelembagaan Kementerian Koperasin dan Usaha Kecil dan Menengah, pada tanggal 2 Desember 2016. 
merupakan kebijakan dari pemerintah dalam hal ini Kementerian Koperasi dan UKM. Dan apabila Keputusan Menteri Negara Koperasi dan Usaha Kecil dan Menengah Nomor 98/Kep/M.KUKM/IX/2004 tentang Notaris Sebagai Pembuat Akta Koperasi tersebut ingin dibuktikan ada atau tidaknya implikasi dalam pembuatan akta pendirian tersebut, yaitu dengan Uji materril atau menyegerakan Rancangan Undang-undang Perkoperasian yang sudah dalam proses tahap pembahasan di DPR dan pemerintah, disahkan menjadi Undangundang Perkoperasian yang baru menggantikan Undang-undang Nomor 25 Tahun 1992 tentang Perkoperasian.

Salah satu Notaris dan PPAT Jawa Tengah yang belum sebagai Notaris Pembuat Akta Koperasi menyatakan bahwa ${ }^{14}$ dengan adanya Keputusan Menteri Negara Koperasi dan Usaha Kecil dan Menengah Nomor 98/Kep/M.KUKM/IX/2004 tentang Notaris Sebagai Pembuat Akta Koperasi, kewenangan Notaris berdasarkan Pasal 15 ayat (1) UUJN-P, justru terbatasi. Notaris merupakan pejabat publik yang diberikan kewenangan oleh pemerintah untuk membuat suatu akta autentik, tanpa terkecuali akta pendirian koperasi yang merupakan badan hukum. Ketentuan dalam Keputusan Menteri Negara Koperasi dan Usaha Kecil dan Menengah Nomor 98/Kep/M.KUKM/IX/2004 tentang Notaris Sebagai Pembuat Akta Koperasi, menyatakan bahwa akta pendirian koperasi harus dibuat di hadapan Notaris, dan Notaris yang membuat akta pendirian tersebut adalah Notaris yang telah terdaftar sebagai Notaris Pembuat Akta Koperasi yang telah mengikuti pembekalan perkoperasian yang diselenggarakan oleh kementerian koperasi dengan Organisasi INI. Padahal, keputusan MK yang telah membatalkan Undang-Undang Nomor 17 Tahun 2012 tentang Perkoperasian secara keseluruhan, dan menyatakan berlakunya kembali Undang-Undang Nomor 25 Tahun 1992 tentang Perkoperasian, selama beluma danya Undang-undang Perkoperasian yang baru tidak menyebutkan bahwa akta pendirian koperasi harus dibuat dengan akta autentik, hal ini memberikan peluang bagi orang-orang yang ingin mendirikan sebuah koperasi untuk mendirikan koperasi dengan akta di bawah tangan. Hal ini tidak berlaku apabila undang-undang Perkoperasian dengan tegas menyatakan bahwa akta pendirian koperasi harus dengan akta autentik. Hal ini menurut Notaris dan PPAT Jawa Tengah yang belum mempunyai NPAK tersebut bertentangan dengan prinsip dasar keadilan distributif pemikiran Aristoteles yang dikenal sebagai keadilan ekonomi adalah distribusi ekonomi yang merata atau yang dianggap adil bagi semua warga negara.

${ }^{14}$ Hasil wawancara dengan Notaris dan PPAT Banyumas Jawa Tengah, Notaris dan PPAT yang bukan merupakan Notaris Pembuat Akta Koperasi, pada tanggal 22 November 2016. 
Pengurus Pusat organisasi Ikatan Notaris Indonesia, Agung Iriantoro (Ketua Bidang Perlindungan Anggota INI) juga menyatakan bahwa di dalam pelaksanaannya, meskipun Undang-Undang Nomor 25 Tahun 1992 tentang Perkoperasian saat ini tidak mengharuskan pendiriannya menggunakan akta autentik, akan tetapi pelaksanaannya koperasi-koperasi dalam pembuatan pendiriannya menggunakan akta notariil. Apabila dipermasalahkan ada atau tidaknya implikasi hukum terkait dengam Keputusan Menteri Koperasi dan Usaha Kecil dan Menengah Nomor 98/Kep/M.KUKM/IX/2004 tentang Notaris Sebagai Pembuat Akta Koperasi sebagai dasar notaris dalam pembuatan akta koperasi dengan UUJN-P sebagai payung hukum notaris dalam menjalankan jabatannya yang memiliki kewenangan dalam pembuatan seluruh akta autentik, sebenarnya belum memiliki implikasi hukum terhadap akta pendirian koperasi dikarenakan belum ada permasalahan di lapangan terkait kebsahan akta koperasi yang dibuat oleh notaris dan selama belum adanya Undang-undang yang baru mengatur tentang perkoperasian dalam hal ini yang berkaitan dengan kewenangan Notaris dalam pembuatan akta koperasi.

\section{Keabsahan}

Dari segi hierarki perundang-undangan, yakni Pasal 7 Undang-undang Nomor 12 Tahun 2011 tentang Pembentukan Peraturan Perundang-undangan menyatakan, Jenis dan hierarki Peraturan Perundang-undangan terdiri atas:

a. Undang-undang Dasar Negara Republik Indonesia Tahun 1945

b. Ketetapan Majelis Permusyawaratan Rakyat

c. Undang-Undang/Peraturan Pemerintah Pengganti Undang-undan;

d. Peraturan Pemerintah

e. Peraturan Presiden

f. Peraturan Daerah Provinsi, dan

g. Peraturan Daerah Kabupaten/Kota.

Berdasarkan hierarki peraturan perundang-undangan tersebut di atas, maka Keputusan Menteri Negara Koperasi dan Usaha Kecil dan Menengah Nomor 98/Kep/M.KUKM/IX/2004 tentang Notaris Sebagai Pembuat Akta Koperasi, maka keberadaannya tidak boleh bertentangan dengan aturan yang lebih di atasnya, dalam hal ini Undang-undang Nomor 25 Tahun 1992 tentang Perkoperasian. Atau dalam istilah hukum disebut sebagai Asas lex superior derogat legi inferior yang artinya peraturan yang lebih tinggi mengesampingkan yang rendah (asas hierarki), dalam kerangka berfikir mengenai jenis dan hierarki peraturan perundang-undangan, pasti tidak terlepas dalam benak kita menganai Teori Stuffen Bow karya Hans Kelsen atau yang sering dikenal dengan "Teori Aquo". 
Sebagai aturan pelaksanaan terkait dengan akta pendirian koperasi atas UndangUndang Nomor 25 Tahun 1992 tentang Perkoperasian, Menteri Koperasi dan Usaha Kecil dan Menengah telah mengeluarkan Keputusan Menteri Negara Koperasi dan Usaha Kecil dan Menengah Nomor 98/Kep/M.KUKM/IX/2004 tentang Notaris Sebagai Pembuat Akta Koperasi. Keputusan Menteri Negara Koperasi dan Usaha Kecil dan Menengah Nomor 98/Kep/M.KUKM/IX/2004 tersebut, dibuat dengan dasar pertimbangan bahwa dalam rangka meningkatkan mutu pelayanan hukum dalam bidang perkoperasian, khususnya yang berkaitan dengan proses, prosedur dan tata cara pendirian, perubahan anggaran dasar dan akta-akta lain yang terkait dengan kegiatan koperasi, diperlukan adanya upaya untuk menjamin kepastian hukum terhadap akta-akta perkoperasian melalui penggunaan akta autentik. $^{15}$

Pasal 7 dalam Keputusan Menteri Negara Koperasi dan Usaha Kecil dan Menengah Nomor 98/Kep/M.KUKM/IX/2004 tentang Notaris Sebagai Pembuat Akta Koperasi menyebutkan, Pembentukan Koperasi dilakukan dengan akta pendirian (akta perjanjian yang dibuat oleh para pendiri) dalam rangka pembentukan koperasi yang memuat Anggaran Dasar. Notaris Pembuat Akta Koperasi (selanjutnya disebut dengan NPAK) adalah pejabat umum yang diangkat berdasarkan Peraturan Jabatan Notaris, yang diberi kewenangan untuk membuat akta pendirian, akta perubahan anggaran dasar dan akta-akta lainnya yang terkait dengan kegiatan koperasi. ${ }^{16}$ Untuk melaksanakan pembuatan akta-akta tersebut, NPAK sebagai pejabat pembuat akta koperasi perlu memiliki pengetahuan dan pemahaman tentang perkoperasian.

Selanjutnya Menteri Koperasi dan Usaha Kecil dan Menengah mengeluarkan sebuah Peraturan Menteri Koperasi dan Usaha Kecil dan Menengah Republik Indonesia Nomor 10/Per/M.KUKM/IX/2015 Tentang Kelembagaan Koperasi. Dasar pertimbangan dikeluarkannya Peraturan Menteri Koperasi dan Usaha Kecil dan Menengah Republik Indonesia Nomor 10/Per/M.KUKM/IX/2015 Tentang Kelembagaan Koperasi ini adalah, bahwa untuk meningkatkan status kelembagaan dan tertib administrasi badan hukum koperasi sesuai Undang-undang Nomor 25 Tahun 1992 tentang Perkoperasian dan ketentuan Pasal 9 ayat (1), ayat (2), dan lampiran huruf q Undang-Undang Nomor 23 Tahun 2014 tentang Pemerintahan Daerah, perlu dilakukan penyempurnaan sistem dan prosedur

${ }^{15}$ Lihat bagian menimbang Keputusan Menteri Negara Koperasi dan Usaha Kecil dan Menengah Nomor 98/Kep/M.KUKM/IX/2004 tentang Notaris Sebagai Pembuat Akta Koperasi.

${ }^{16}$ Ibid. 
pembentukan, pengesahan akta pendirian, perubahan anggaran dasar, penggabungan, pembagian dan peleburan serta pembubaran koperasi agar dapat memberikan kepastian hukum. ${ }^{17}$

\section{Penutup}

Hasil penelitian menyimpulkan, pertama: Putusan Mahkamah Konstitusi Nomor 28/PUU-XI/2013 yang mencabut keberlakuan Undang-Undang Nomor 17 Tahun 2012 tentang Perkoperasian, sekaligus menyatakan berlakunya kembali Undang-Undang Nomor 25 Tahun 1992 tentang Perkoperasian sampai dengan dikeluarkannya Undang-undang Koperasi yang baru, hal ini mengakibatkan terjadinya pergeseran peraturan Undang-undang tentang perkoperasian untuk sementara waktu yakni kembali pada Undang-Undang Nomor 25 Tahun 1992 tentang Perkoperasian sampai diterbitkannya Undang-undang baru tentang perkoperasian tersebut. Oleh karena itu seluruh prosedur dan tata cara pendirian koperasi sejak tanggal dibatalkannya secara keseluruhan Undang-Undang Nomor 17 Tahun 2012 tentang Perkoperasian oleh Mahkamah Konstitusi dan kembali pada Undang-Undang Nomor 25 Tahun 1992 tentang Perkoperasian beserta seluruh peraturan pelaksanaanya. Sedangkan kekuatan hukum atas akta pendirian koperasi yang dibuat pasca Putusan MK Nomor 28/PUU-XI/2013, menurut Kementerian Koperasi dan UKM sebagai pembuat kebijakan dan pengesahan badan hukum koperasi tetap menjadikan akta pendirian koperasi yang akta pendiriannya dibuat oleh notaris dan disahkan Badan Hukumnya oleh Kementerian Koperasi dan UKM tetap memiliki kekuatan pembuktian lahiriah, kekuatan pembuktian formil, maupun nilai pembuktian materiil, dan apabila kebijakan dari Kementerian Koperasi dan UKM berdasarkan Keputusan Menteri Nomor 98/KEP/M.KUKM/IX/2004 tentang Notaris Sebagai Pembuat Akta Koperasi dianggap bertentangan dengan peraturan yang ada di atasnya serta tidak memiliki kekuatan hukum, maka perlu dilakukan uji materiil terhadap Keputusan Menteri tersebut. Kedua, implikasi Keputusan Menteri Nomor 98/KEP/M.KUKM/IX/2004 tentang Notaris Sebagai Pembuat Akta Koperasi, sesuai dengan kewenangan yang diberikan oleh UUJN-P, menjadi terbatas. Karena Keputusan Menteri Nomor 98/KEP/M.KUKM/IX/2004 tentang Notaris Sebagai Pembuat Akta Koperasi tersebut mengatur bahwa Notaris pembuat akta koperasi, harus mengikuti pembekalan tentang perkoperasian yang diadakan oleh Menteri Koperasi dan Usaha Kecil dan Menengah yang telah bekerjasama dengan organisasi Ikatan Notaris

${ }^{17}$ Lihat dasar menimbang pada Peraturan Menteri Koperasi dan Usaha Kecil dan Menengah Republik Indonesia Nomor 10/Per/M.KUKM/IX/2015 Tentang Kelembagaan Koperasi. 
Indonesia. Kedudukan Keputusan Menteri Nomor 98/KEP/M.KUKM/IX/2004 tentang Notaris Sebagai Pembuat Akta Koperasi bukan merupakan instruksi dari Undang-undang 25 Tahun 1992 tentang Perkoperasian. Sehingga keberadaan Keputusan Menteri Nomor 98/KEP/M.KUKM/IX/2004 tentang Notaris Sebagai Pembuat Akta Koperasi ini, tetap berjalan sebelum adanya uji materiil atau disahkannya Undang-undang tentang Perkoperasian yang baru yang sedang dalam tahap pembahasan oleh Pemerintah dan DPR.

\section{Daftar Pustaka}

Ervianty, Orriza Julia, Analisis Hukum Atas Tugas dan Peranan Notaris Dalam Pendirian Koperasi Sebelum dan Setelah Berlakunya Undang-undang Nomor 17 Tahun 2012 Tentang Perkoperasian dan Pasca Keluarnya Putusan Mahkamah Konstitusi Republik Indonesia Nomor 28/PUU-XI/2013.

Kementerian Koperasi dan Usaha Kecil dan Menengah Republik Indonesia, Undangundang Nomor 25 Tahun 1992 Tentang Perkoperasian (Notaris Pembuat Akta Koperasi), Deputi Bidang Kelembagaan Koperasi dan UKM, Jakarta, 2014.

Keputusan Menteri Negara Koperasi dan Usaha Kecil dan Menengah Nomor 98/Kep/M.KUKM/IX/2004 tentang Notaris Sebagai Pembuat Akta Koperasi.

Kitab Undang-undang Hukum Perdata.

Kusuma, Hadi, Koperasi Indonesia, Jakarta, Raja Grafindo Persada, 2006.

LPS21, Kajian Akademik Rancangan Undang-undang Koperasi, Jakarta, 2001.

Mertokusumo, Sudikno, Hukum Acara Perdata Indonesia (edisi keempat), Yogyakarta: Liberty,1993.

Nota Kesepahaman (MoU) Kementerian Koperasi dan UKM RI dengan Ikatan Notaris Indonesia (INI) tertanggal 4 Mei 2004.

Peraturan Menteri Koperasi dan Usaha Kecil dan Menengah Republik Indonesia Nomor 10/Per/M.KUKM/IX/2015 Tentang Kelembagaan Koperasi.

Putusan Mahkamah Konstitusi Nomor 28/PUU-XI/2013

Sudarsono dan Edilidius, Koperasi Dalam Teori dan Praktik, Jakarta: Rineka Cipta, 2010.

Suroto, Pelatihan Perkoperasian, Jakarta, 2015.

Undang-Undang Nomor 2 Tahun 2014 tentang Perubahan Atas Undang-undang Nomor 30 Tahun 2004 tentang Jabatan Notaris.

Undang-Undang Nomor 25 Tahun 1992 tentang Perkoperasian.

Untung, H. Budi, Hukum Koperasi dan Peranan Notaris Indonesia, Yogyakarta: ANDI, 2007.

Wawancara dengan Basuki, Assisten Deputi Bidang Perundang-undangan, deputi kelembagaan Kementerian Koperasin dan Usaha Kecil dan Menengah, pada tanggal 2 Desember 2016. 
Wawancara dengan Notaris dan PPAT Banyumas Jawa Tengah, Notaris dan PPAT yang bukan merupakan Notaris Pembuat Akta Koperasi, pada tanggal 22 November 2016. 